\title{
Perbandingan Penyelesaian Kasus Pelanggaran Hak Asasi Manusia Antara Indonesia dan Afrika Selatan (Perspektif Lembaga Pelaksana dan Upaya Kedepan)
}

\section{Iwa Kustiwa}

Program Magister Ilmu Hukum Universitas Padjadjaran, Email: iwakustiwa57@gmail.com,

\section{Supriyadi A Arief}

Program Magister Ilmu Hukum Universitas Padjadjaran, Email: supriyadi18001@mail.unpad.ac.id.

\begin{abstract}
The process of resolving human rights cases in Indonesia and Soutf Africa is carried out by the same institution. However, Truth and Reconcilliation Commission (TRC/KKR) in South Africa is more visible than the TRC chich was formed in Indonesia. Moreever, after the Constitutional Court decision dismissed the KKR in Indonesia. Therefore, it is important to outline the institutions between the KKR in Indonesia and South Africa, as well as to reformulate steps that the Indonesia government. In practice, the implementation of the TRC/KKR duties through clear duties, functions, regulations, and the role of national figures will also support TRC/KKR performance in resolving human rights which is practiced by the TRC in South Africa. There is space provided by the Constitutional Court so that the human rights settlement process can be carried out through the reconciliation process must be followed up by the Indonesian Government quickly and precisely.
\end{abstract}

Keyword: Truth and Reconcilliation Commission; Human Rights; Indonesia; South Africa.

\section{PENDAHULUAN}

Hak asasi manusia (selanjutnya ditulis HAM) merupakan hak alamiah melekat pada setiap individu sebagai karunia tuhan yang maha kuasa. Dalam Pasal 1 Undang-Undang Nomor 39 Tahun 1999 Tentang Hak Asasi Manusia, HAM dijabarkan sebagai "Seperangkat hak yang melekat pada hakikat dan keberadaan manusia sebagai mahkluk Tuhan Yang Maha Esa dan merupakan anugerah-Nya yang wajib dihormati, dijunjung tinggi dan dilindungi oleh negara, hukum dan pemerintah, dan setiap orang demi kehormatan serta harkat dan martabat manusia”. Merujuk kedudukannya yang sangat penting dalah kehidupan manusia, maka persolan HAM harus mendapat jaminan serta perlindungan, utamanya oleh negara.

Tujuan dari pembentukan negara ialah tidak lain agar hak rakyat dapat dilindungi dan dipenuhi. Sebagai individu, rakyat membutuhkan organisasi yang memiliki kekuasaan untuk menjamin agar hak mereka tidak dilanggar oleh orang lain, juga untuk memenuhi hak yang tidak mungkin dipenuhi secara individual. ${ }^{1}$ Dengan demikian, perlindungan

\footnotetext{
${ }^{1}$ Janedri M.Gaffar, (2012), Demokrasi Konstitusional: Praktik Ketatanegaraan Indonesia Setelah Perubahan UUD 1945, Jakarta: Konstitusi Press, hlm. 30.
} 
bagi setiap warga negara dalam kerangka pemenuhan hak asasinya merupakan kewajiban yang harus dipenuhi oleh suatu negara.

HAM sebagai hak alamiah, menjadikan negara atau pemerintah tidak boleh mengganggu atau merampas hak-hak alamiah, yaitu life, liberty, property sebagaimana disampaikan oleh John Locke dalam buku Two Treaties of Civil Government:

"But though men when they enter into society give up the equality, liberty, and executive power they had in the state of Nature into the hands of society, to be so far disposed of by the legislative as the good society shall require, yet it being only with the intention in everyone the better preserve himself, his liberty and property, ... the power of the society or legislative constitute by them can never be supposed to extend further than the common good but is obliged to secure everyone's property by providing against those three defects above menOoned that made the state of Nature an uneasy. ${ }^{2}$

Lahirnya deklarasi universal hak asasi manusia (Universal Declaration of Human Rights) tahun 1948 sebagai deklarasi memorial kemanusiaan membawa konsekuensi terhadap setiap negara anggota PBB untuk mengakui hak-hak setiap orang sebagai hak asasi yang harus dihormati, guna mencegah atau setidak-tidaknya mengurangi berbagai tindakan dan kebijakan negara yang sewenang-wenang terhadap individu warganya. Berangkat dari hal tersebut maka posisi hak asasi manusia merupakan hal yang vital dalam mendukung terwujudnya suatu negara berdasarkan hukum. Oleh sebab itu, setiap tindakan yang terindikasi adanya pelanggaran terhadap hak-hak asasi manusia merupakan tindakan yang harus mendapat perhatian khusus, baik itu dilakukan oleh individu, kelompok, maupun oleh negara. ${ }^{3}$

Bentuk pelanggaran HAM di Indonesia tercerminkan dari kejadian berupa penangkapan yang tidak sah, penculikan, penganiyaan, perkosaan, penghilangan paksa, bahkan pembunuhan, pembakaran rumah tinggal dan tempat ibadah penyerangan pemuka agama beserta keluarganya. Selain itu, terjadi pula penyalagunaan kekuasaan oleh pejabat publik dan aparat negara yang seharusnya menjadi penegak hukum, pemeliharaan keamanan, dan perlindungan rakyat, tetapi justru mengintimidasi, menganiaya, menghilangkan paksa dan atau menghilangkan nyawa. ${ }^{4}$

Beberapa contoh kasus tersebut dapat terlihat dari peristiwa pelanggaran HAM yang terjadi dalam peristiwa pembantaian PKI pada Tahun (1965-1966), Tanjung Priok (1984), Talang Sari, Lampung (1989), penghilangan orang secara paksa (1997- 1998), kerusuhan Mei (1998), Trisakti (1998), Semanggi I (1998) dan Semanggi II (1999), Timor-Timur (1999). Pada praktiknya, setelah reformasi terjadi proses penyelesaian pelanggaran HAM di Indonesia dilakukan dengan dua mekanisme, yakni melalui pengadilan HAM, dan melalui proses rekonsiliasi berupa upaya pemulihan kembali hakhak korban serta menelusuri kebenaraan pelanggaran HAM yang pernah terjadi di masa lalu. Opsi kedua ini dilakukan melalui mekanisme pembentukan lembaga Komisi

\footnotetext{
${ }^{2}$ Clarence Morris (eds), The Great Legal Philosophers, dikutip dalam Bagir Manan dan Susi Dwi Harijanti, "Konstitusi dan Hak Asasi Manusia", Padjajaran Jurnal Ilmu Hukum, Vol. 3, No. 3, Tahun 2016, hlm. 450.

3 Secara khusus di Indonesia, pembahasan serta pengaturan tentang pelanggaran HAM telah dirumuskan dalam UU 39 tahun 1999, khususnya dalam Pasal 1 angka 6.

${ }^{4}$ Lihat Penjelasan Atas Undang-Undang Nomor 39 Tahun 1999 Tentang Hak Asasi Manusia Paragraf 6
} 
Kebenaran dan Rekonsiliasi (KKR) melalui Undang-Undang Nomor 27 Tahun 2004 tentang Komisi Kebenaran dan Rekonsiliasi.

Sebagai perbandingan, di Afrika Selatan juga terjadi kasus pelanggaran HAM. Pelanggaran HAM di Afrika Selatan bermula sejak Partai Nasional de Boer 1948 memenangkan pemilihan umum dan membentuk pemerintahan minoritas kulit putih, sistem apartheid kemudian ditetapkan dalam undang-undang. Pada tahun 1950, Undang-undang Pendaftaran Populasi semua warga Afrika Selatan dibagi dalam tiga kategori ras, yaitu Bantu atau Afrika kulit hitam, kulit putih dan kulit berwarna lainnya. ${ }^{5}$

Pemisahan warga kulit putih dan hitam juga diberlakukan di fasilitas umum. Gedunggedung umum, transportasi umum, taman-taman, rumah makan, serta tentu sekolahsekolah, perguruan tinggi, rumah sakit dan gereja. Daerah-daerah permukiman di setiap kota dan desa juga dibagi dua, sistem pendidikan sekolah terpisah dengan kualitas guru yang berbeda, dan hanya warga kulit putih yang memiliki hak pilih. ${ }^{6}$ Hampir serupa dengan Indonesia, penyelesaian pelanggaran HAM di Afrika Selatan juga dilakukan melalui mekanisme Komisi Kebenaran dan Rekonsiliasi (Truth and Reconcilliation Commission).

Merujuk dua perbandingan singkat tersebut, terdapat kesamaan model antara Indonesia dan Afrika Selatan. Akan tetapi, adanya peran Komisi Kebenaran dan Rekonsiliasi dalam penyelesaian pelanggaran HAM antara dua negara tersebut kemudian tidak menjamin proses penyeleasaian HAM dapat dilakukan secara tuntas. Keberadaan KKR di Afrika Selatan dikatakan berhasil dan menjadi rujukan dari berbagai negara termasuk Indonesia dalam proses penyelesaian pelanggaran HAM yang terjadi. Akan tetapi, hal yang bebeda justru terjadi di Indonesia. Mekanisme penyelesaian pelanggaran HAM oleh KKR justru tidak berjalan dengan baik, terlebih lagi setelah lahirnya putusan Mahkamah Konstitusi Nomor 006/PUU-IV/2006 yang secara garis besar menyatakan bahwa UU Nomor 27 Tahun 2004 bertentangan dengan Undang-Undang Dasar Negara Republik Indonesia Tahun 1945. Hal ini tentu berimplikasi pada kedudukan lembaga KKR yang secara otomatis juga tidak diakui keberadannya sekaligus juga berdampak pada proses penyelesaian dan pemulihan pelanggara HAM di Indonesia.

\section{METODE PENELITIAN}

Tulisan merupakan kajian yang menggunakan jenis penelitian normatif atau penelitian hukum kepustakaan. Penelitian normatif adalah penelitian hukum yang dilakukan dengan cara meneliti data sekunder belaka. ${ }^{7}$ Data sekunder diperoleh dari dari bahanbahan pustaka. ${ }^{8}$ Dalam penelitian hukum, data sekunder mencakup: pertama, bahan hukum primer yang merupakan bahan hukum yang mengikat seperti norma atau kaidah dasar (pembukaan UUD 1945), peraturan dasar (UUD 1945), peraturan perundangundangan, bahan hukum yang tidak dikodifikasikan, yurisprudensi, traktat. Kedua, bahan hukum sekunder yang memberikan penjelasan mengenai bahan hukum primer

5 Aparteid merupakan sistem pemisahan ras yang diterapkan oleh pemerintah kulit putih di Afrika Selatan dari awal abad ke-20 hingga tahun 1990. Luky Setyarini, Apartheid di Afrika Selatan-Dunia Hitam-Putih https://www.dw.com/id/apartheid-di-afrika-selatan-dunia-hitamputih/a 5239303. Diakses 10 November 2020.

${ }^{6}$ Ibid.

${ }^{7}$ Soerjono Soekanto dan Sri Mamudji, (2014), Penelitian Hukum Normatif Suatu Tujuan Singkat, Cetakan ke-11, Jakarta: PT Raja Grafindo Persada, hlm 13.

${ }^{8}$ Idem, hlm 12. 
seperti hasil penelitian. Ketiga, bahan hukum tertier yang merupakan bahan hukum yang memberikan petunjuk maupun penjelasan terhadap bahan hukum primer dan sekunder. ${ }^{9}$

Dalam penelitian ilmu hukum normatif banyak pendekatan yang dapat digunakan baik secara terpisah-pisah berdiri sendiri maupun secara kolektif sesuai degan isu atau permasalahan yang dibahas. ${ }^{10}$ Pendekatan tersebut antara lain: pendekatan perundangundangan, pendekatan historis, pendekatan konseptual, pendekatan komparatif, pendekatan politis, serta pendekatan kefilsafatan. ${ }^{11}$ Adapun dalam tulisan ini lebih difokuskan pada pendekatan perundang-undangan, pendekatan historis, pendekatan konseptual, pendekatan komparatif. Melalui pendekatan tersebut, diharapkan dapat mendapatkan jawaban dari permasalahan yang dikaji.

\section{ANALISIS}

\section{Proses Penyelesaian Pelanggaran HAM di Indonesia}

Proses penyelesaian pelanggaran HAM di Indonesia sebagai satu kesatuan dari penataan ketatanegaraan Indonesia dapat dibagi dalam beberapa fase, sebagai berikut:

\section{a) Potret Kasus Pelanggaran HAM Yang Pernah Terjadi}

Kasus pelanggaran hak asasi manusia di Indonesia telah tercatat terjadi sejak pasca kemerdekaan hingga setelah terjadinya reformasi 1999. Sebagai contoh, pembantaian massal 1965 merupakan kasus pelanggaran HAM berat yang mengakibatkan 1.500.000 korban tewas dan hilang. Disusul penembakan misterius Petrus dengan 1.678 korban, kemudian kerusuhan Mei 1998 dengan 1.308 korban. ${ }^{12}$ Secara runtut, beberapa kasus pelanggaran HAM yang pernah terjadi di Indonesia diantaranya adalah:

1) Pembataian Masal 1965.

Peristiwa ini dilatarbelakangi atas dasar tuduhan bahwa Partai Komunis Indonesia (PKI) dalang dari pembunuhan tujuh perwira jenderal, yang terjadi pada tanggal 30 September 1965 dan lebih dikenal dengan peristiwa G30S/PKI. Akibat dari gerakan tersebut dikeluarkannya kebijakan negara untuk meniadakan partai tersebut dan diikuti tindakan kekerasan terhadap warga negara yang dituduh sebagai anggota maupun simpatisan PKI. Tindakan tersebut dilakukan dengan cara-cara represif yang berdampak pada jatuhnya korban jiwa maupun luka-luka. ${ }^{13}$

Dalam catatan Komisi Nasional Hak Asasi Manusia (KOMNAS HAM) operasi pembersihan PKI diperkirakan 500.000 hingga 3 juta warga tewas dibunuh saat itu. Ribuan lainnya diasingkan, dan jutaan orang lainnya harus hidup dibawah bayangbayang 'cap PKI' selama bertahun-tahun. ${ }^{14}$ Komnas HAM menuding Komando Operasi

${ }^{9}$ Idem, hlm. 13.

${ }^{10}$ Bahder Johan Nasution, (2008), Metode Penelitian Ilmu Hukum, Bandung: Mandar Maju, hlm. 92.

${ }^{11}$ Idem, hlm. 93.

12 Tim Monitoring dan Dokumentasi SETARA Institute, Data Pelanggaran Hak Asasi manusia di Indonesia, h. 1-3, http://setara-institute.org/wp-content/uploads/2015/09/Data-Pelanggaran-Hak-AsasiManusia-di-Indonesia.pdf, diakses tanggal 12 November 2020.

13 Ringkasan Eksekutif, Laporan Penyelidikan Pelanggaran Ham Yang Berat, Jakarta : Komnas HAM, hlm 3.

14 Febriana Firdaus, Lima Kasus Besar Pelanggaran HAM di Indonesia, https://www.rappler.com/world/regions/asia-pacific/indonesia/77617-lima-kasus-besar-pelanggaran-hamdi-indonesia, diakses 12 November 2020. 
Pemulihan Kemanan dan semua panglima militer daerah yang menjabat saat itu sebagai pihak yang paling bertanggung-jawab. ${ }^{15}$ Sebagai catatan, Laporan hasil penyelidikan telah diserahkan kepada Kejaksaan Agung pada tanggal 31 tahun 2000. Kasus ini telah disidik oleh Kejaksaan Agung dan diperiksa pengadilan dan telah sampai pada tingkat kasasi. Satu terdakwa dinyatakan bersalah. ${ }^{16}$

2) Kerusuhan Mei 1998

Runtuhnya kekuasaan orde baru pada tahun 1999 jutsru menimbulkan berbagai pelanggaran HAM. Berbagai kasus tersebut, yakni: pertama, penghilangan paksa. Berdasarkan laporan penyelidikan Tim Ad Hoc Komnas HAM, setidaknya 23 aktivis pro demokrasi menjadi korban. Hingga sekarang, sembilan orang dikembalikan, satu orang meninggal dunia, dan 13 orang masih hilang. ${ }^{17}$ Kedua, penembakan mahasiswa Trisakti. Pada 13-15 Mei 1998, terjadi kerusuhan masif yang diawali oleh kondisi krisis finansial Asia. Kondisi ini membuat situasi Ibu Kota Jakarta makin memburuk. Hal ini dipicu oleh tewasnya empat mahasiswa Universitas Trisakti yang tertembak dalam demonstrasi pada 12 Mei $1998 .^{18}$

Ketiga, Tragedi Semanggi I yang terjadi pada 13 November 1998. Saat itu mahasiswa berdemonstrasi menolak Sidang Istimewa MPR yang dinilai inkonstitusional, menuntut dihapusnya dwifungsi ABRI, dan meminta Presiden segera mengatasi krisis ekonomi. Ketika mahasiswa mencoba bertahan dari tindakan aparat bersenjata lengkap dan kendaraan lapis baja, terjadi penembakan kearah mahasiswa. Setidaknya lima orang mahasiswa menjadi korban serta melukai sebanyak 253 orang lainnya. ${ }^{19}$ Keempat, Tragedi Semanggi II yang terjadi pada 24 September 1999, saat mahasiswa menolak rencana pemberlakuan UU Penanggulangan Keadaan Bahaya. Aksi penolakan yang dilakukan oleh mahasiswa kembali menelan 11 orang yang meninggal dunia akibat penembakan yang dilakukan oleh aparat keamanan. ${ }^{20}$

Potret pelanggaran HAM yang terjadi selama sebelum dan proses reformasi tidak satupun terselesaikan dengan jelas dipengadilan HAM. Bahkan, hingga kini para kelurga korban selalu melakukan aksi kamisan untuk menyuarakan penuntasan berbagai pelanggaran HAM tersebut. Pelanggaran HAM yang terjadi di Indonesia tidak hanya terhenti pada kasus-kasus tersebut. Apabila di inventarisir, masih terdapat beberapa kasus pelanggaran HAM, misalnya: pelanggaran HAM berat yang terjadi pasca Jajak Pendapat di Timor-Timor, Peristiwa Malari, pelanggaran HAM yang terjadi di Aceh dan di Papua, hingga pelanggaran HAM yang berbasis suku, agama, ras, dan antar golongan yang terjadi di Maluku, Poso, Sampit. Dari keseluruhan peristiwa tersebut, belum ada yang diselesaikan secar tuntas oleh negara, baik melalui proses pengadilan HAM atau bahkan melalui KKR (sebelum dibubarkan).

\footnotetext{
15 Ibid.

${ }^{16}$ Firdiansyah, Peran dan Harapan Korban Untuk Penyelesaian Pelanggaran HAM Masa Lalu, Jurnal HAM Komnas HAM, Vol. XIII. Tahun 2016, hlm 5.

17 Rakaryan Sukarjaputra, Konflik dan Pelanggaran HAM Catatan Kelam 20 tahun Reformasi, https://nasional.kompas.com/jeo/konflik-dan-pelanggaran-ham-catatan-kelam-20-tahun-reformasi, diakses 13 November 2020.

${ }^{18}$ Febriana, Op.cit.

${ }^{19}$ Rakaryan Sukarjaputra, Op.cit.

${ }^{20}$ Ibid.
} 


\section{b) Penyelesaian HAM oleh KKR Indonesia}

Seperti yang diketahui, di Indonesia proses penyelesaian pelanggaran HAM dilakukan melalui didua tahap, yakni melalui Pengadilan HAM ad-hoc serta melalui Komisi Kebenaran dan Rekonsiliasi (KKR). Secara khusus,KKR merupakan penamaan umum terhadap komisi yang dibentuk pada situasi transisi politik dalam rangka menangani pelanggaran berat atau kejahatan HAM di masa lalu. ${ }^{21}$

Pembentukan KKR di Indonesia merupakan mandat utama dari Ketetapan (TAP) MPR No. V/MPR/2000 tentang Pemantapan Persatuan Nasional. Secara lengkap di dalam paragraf kedua Maksud dan Tujuan ditetapkannya ketetapan MPR dimaksud ialah:

"Kesadaran dan komitmen yang sungguh-sungguh untuk memantapkan persatuan dan kesatuan nasional harus diwujudkan dalam langkah-langkah nyata, berupa pembentukan Komisi Kebenaran dan Rekonsiliasi, serta merumuskan Etika Berbangsa dan Visi Indonesia Masa Depan”.

Implementasi TAP MPR ini menyebutkan pembentukan Komisi Kebenaran dan Rekonsiliasi Nasional sebagai sebuah lembaga ekstra-yudisial yang jumlah dan anggota dan kriterianya ditetapkan dengan undang-undang. Pembentukan KKR juga dimandatkan oleh UU No. 26 Tahun 2000 tentang Pengadilan Hak Asasi Manusia, khususnya terkait dengan penyelesaian pelanggaran HAM berat ${ }^{22}$.

Merujuk pada dua perundang-undangan tersebut dan setelah melalui proses pembahasan di DPR, di tahun 2004 lahir Undang-Undang Nomor 2007 tentang Komisi Kebenaran dan Rekonsiliasi. Dalam perjalanannya, UU KKR nyaris tak menujukkan peran dalam menyelesaikan masalah HAM di masa lalu. KKR yang dibentuk atas perintah UU seolah tidak memiliki peran yang signifikan. Tidak maksimalnya pembentukan kelembagaan KKR di Indonesia, semakin kompleks dengan proses judicial review terhadap UU a quo yang diajukan oleh Tim Advokasi Kebenaran dan Keadilan (TAKK) ke Mahkamah Konstitusi.

Melalui proses panjang di Mahkamah Konstitusi (MK), permohonan yang hanya memohonkan pembatalan terhadap tiga pasal, yakni Pasal 1 ayat (9), pasal 27 dan Pasal 44, justru direspon oleh MK dengan membatalkan keseluruhan isi UU. Lahirnya putusan ini tentu menjadi problem sebab KKR tidak diakui lagi keberadaannya. Praktis, penyelesaian HAM lebih difokuskan pada proses pengadilan HAM.

Hal lain yang menjadikan lemahnya penyelesaian pelanggaran HAM oleh KKR pada saat itu dikarenakan selain kurangnya peran aktif pemerintah saat itu yang masih terbelenggu dengan proses awal reformasi, juga tidak adanya tokoh yang mampu menengahi atau yang dapat mengambil peran lebih dalam proses penyelesaian pelangggaran HAM. Diawal reformasi, para elit politik atau tokoh nasional sibuk melakukan penataan terhadap proses ketatanegaraan. Hal ini berimbas pada kurangnya atensi pada proses penyelesaian HAM melalui KKR.

\section{c) Penyelesaian Pelanggaran HAM Pasca Putusan MK}

Pasal 47 UU MK yang menyatakan bahwa "Putusan mahkamah konstitusi memperoleh kekuatan hukum tetap sejak selesai diucapkan dalam sidang pleno terbuka untuk

21 Ifdhal Kasim, (2000), Briefing Paper Series tentang Komisi Kebenaran dan Rekonsiliasi, Jakarta: Lembaga Studi dan Advokasi Masyarakat, hlm 2.

${ }^{22}$ Lihat Pasal 47 UU Pengadilan HAM. Sedangkan jenis pelanggaran HAM berat diatur dalam pasal 7, Pasal 8, dan Pasal 9. 
umum". Dengan demikian, putusan mahkamah konstitusi memiliki karkteristik khusus, dimana setiap putusan berlaku progresif ke depan dan tidak berlaku surut (retroaktif). Oleh sebab itu, seluru subyek perbuatan hukum masih dianggap sah sebelum adanya putusan mahkamah konstitusi yang akan memuat subyek hukum baru.

Berdasarkan Pasal 47 UU MK tersebut, menurut Fajar Laksono sifat final menunjukkan sekurang-kurangnya 3 (tiga) hal, yaitu: ${ }^{23}$ Pertama, bahwa Putusan MK secara langsung memperoleh kekuatan hukum; Kedua, karena telah memperoleh kekuatan hukum maka Putusan MK memiliki akibat hukum bagi semua pihak yang berkaitan dengan putusan. Semua pihak wajib mematuhi dan melaksanakan Putusan MK. Ketiga, karena merupakan pengadilan pertama dan terakhir, maka tidak ada upaya hukum lain yang dapat ditempuh. Sebuah putusan apabila tidak ada upaya hukum yang dapat ditempuh berarti telah mempunyai kekuatan hukum tetap (in kracht van gewijsde) dan memperoleh kekuatan mengikat (resjudicata pro veritate habetur).

Berdasarkan putusan MK Nomor 006/PUU-IV/2006, tiga pasal yang dimohonkan untuk diuji merupakan pasal yang bersifat sebagai jantung dari apa yang menjadi tujuan UU KKR, sehingga dengan pembatalan pasal ini, maka KKR tidak lagi bisa menjadi tujuannya, karenanya UU KKR perlu dibatalkan secara keseluruhan.

Mengingat posisi MK hanya sebagai negative legislator dan bukan sebagai positif legislator maka hal tersebut menurut penulis menjadi dasar utama MK enggan untuk melakukan perbaikan secara kontruktif pada pasal yang diuji tersebut. Oleh sebab itu, MK justru membatalkan UU tersebut secara keseluruhan. Akan tetapi, MK untuk tutup mata terhadap proses penyelesaian pelanggaran HAM di Indonesia. Hal tersebut ditunjukan oleh MK melalui rekomendsi pembentukan UU KKR yang baru.

"Dengan dinyatakannya UU KKR tidak mempunyai kekuatan hukum mengikat secara keseluruhan, tidak berarti Mahkamah menutup upaya penyelesaian pelanggaran HAM berat di masa lalu melalui upaya rekonsiliasi. Banyak cara yang dapat ditempuh untuk itu, antara lain dengan mewujudkan rekonsiliasi dalam bentuk kebijakan hukum (undang-undang) yang serasi dengan UUD 1945 dan instrumen HAM yang berlaku secara universal, atau dengan melakukan rekonsiliasi melalui kebijakan politik dalam rangka rehabilitasi dan amnesti secara umum,"24

Perintah konstitusional MK untuk membentuk kembali UU KKR yang sejalan dengan UUD 1945 dan hukum HAM internasional, menjadi penting, karena penegasan ini sesungguhnya memiliki arti bahwa MK mengakui urgensi dan konstitusionalitas Komisi Kebenaran dan Rekonsiliasi (KKR), dalam penyelesaian pelanggaran HAM di masa lalu, sebagai bagian dari proses transisi demokrasi. ${ }^{25}$

MK kemudian merekomendasikan untuk dilakukan pengaturan tentang penyelesaian pelanggaran HAM melalui tahapan rekonsiliasi dengan undang-undang yang baru dan sesuai dengan UUD, serta hukum HAM Internasional. Melihat dari keluasan dan kerumitan masalah terkait pelanggaran HAM di masa lalu, tidaklah memungkinkan jika kebijakan politik, apalagi sekedar executive order dipilih sebagai jalan penyelesainnya.

${ }^{23}$ Fajar Laksono Soeroso, “Aspek keadilan Dalam Sifat Final Putusan Mahkamah Konstitusi”, Jurnal Konstitusi, Vol. 11, No.1, Maret 2014, hlm 65-66.

${ }^{24}$ Putusan MK No. 006/PUU-IV/2006, hlm 131.

${ }^{25}$ Lembaga Studi dan Advokasi Masyarakat, Op.cit. hlm 5. 
Pilihan untuk melakukan pembentukan kembali undang-undang, akan lebih memberikan ruang bagi terjadinya negosiasi yang lebih luas, bagi upaya penyelesaian masa lalu. Artinya, dengan pembentukan undang-undang akan membuka partisipasi dari beragam stake holder, maupun masyarakat secara umum, sehingga tidak sekedar menjadi bahan negosiasi politik antar-segelintir elit politik, sebab pembahasan di DPR, mengandaikan adanya keterwakilan dari seluruh rakyat. ${ }^{26}$

Amanat tentang penyelesaian pelanggaran HAM melalui proses pencarian kebenaran dan rekonsiliasi kemudian mulai mendapat titik terang ketika RRU KKR yang merupakan usulan dari Kementerian Hukum dan HAM masuk dalam program legislasi nasional di tahun 2015. Akan tetapi, hingga saat ini belum lahir UU yang mengatur tentang kedudukan KKR yang baru sebagai amanat dari putusan MK Nomor 006/PUUIV/2006. Adanya langkah yang diambil pemerintah ini merupakan langkah maju dari pemerintah untuk berusaha menyelesaikan proses penyelesaian pelanggaran HAM di Indonesia. Selain itu, apabila UU ini disahkan maka proses penyelesaian pelanggaran HAM yang pernah terjadi dan saat ini hanya bertumpu pada proses pengadilan HAM ad-hoc akan berkurang dan beralih ke proses pemulihan dan rekonsisliasi.

\section{Proses Penyelesaian Pelanggaran HAM di Afrika Selatan (Afsel)}

Pasca perang dunia II diskriminasi rasial merupakan salah satu masalah yang sangat besar di Afrika Selatan dengan politik Apartheid-nya yang sangat dominan. Oleh karena itu, Afrika Selatan menjadi rujukan perjuangan anti rasialisme di dunia. Kemenangan Partai Nasional de Boer 1948 dalam pemilihan umum menjadi cikal bakal lahirnya diskriminasi rasial di Afrika Selatan. Orang kulit putih di Afrika Selatan memulai kebijakan pemisahan ras dan warna kulit. Masa yang dikenal sebagai segreration era merupakan cikal bakal dari politik apartheid. Pada masa ini golongan kulit putih mulai melakukan konsolidasi kontrol atas negara, memperkuat cengkeramannya terhadap populasi kulit hitam, dan menghilangkan campur tangan pemerintah Inggris di Afrika Selatan. ${ }^{27}$

Pada tahun 1950, melalui Undang-undang Pendaftaran Populasi semua warga Afrika Selatan dibagi dalam tiga kategori ras, yaitu Bantu (Afrika kulit hitam), kulit putih dan kulit berwarna lainnya. Kemudian ada kategori baru, yaitu Asia yang sebagian besarnya adalah warga etnis India dan Pakistan. Wilayah Afrika Selatan kemudian dibagi menjadi 80 persen wilayah negara itu dimiliki warga kulit putih. Sementara warga kulit hitam ditempatkan di wilayah termiskin yang disebut sebagai homelands atau tanah air. ${ }^{28}$

Perkembangan ekonomi di Homelands tidaklah baik. Sumber daya di daerah tersebut tidak banyak sehingga tidak bisa memenuhi kebutuhan masyarakat, ditambah pertambahan penduduk yang makin meningkat, membuat Homelands menjadi padat dan kumuh. $^{29}$ Kebijakan pemisahan berdampak pada kondisi politik, ekonomi, dan sosial masyarakat kulit hitam dan ras campuran. Diskriminasi yang dilakukan pemerintah justru menyebabkan kesenjangan.

${ }^{26}$ Idem, hlm 5-6.

27 Rifai Shodiq Fathoni, Politik Apartheid di Afrika Selatan 1948-1994 M, https://wawasansejarah.com/politik-apartheid-di-afrika-selatan/, diakses 20 November 2020.

${ }^{28}$ Luky Setyarini, Apartheid di Afrika Selatan, Op.cit.

${ }^{29}$ Agus Budiman, Politik Apartheid di Afrika Selatan, Jurnal Artefak, Vol. 1, No. 1, Januari 2013, $\operatorname{hlm} 20$. 
Inti dari Apartheid adalah setiap kelompok harus membangun dirinya secara terpisah dan harus mencapai otonomi daerahnya masing-masing. Hal ini dijabarkan dalam empat hal, yakni dalam stratifikasi penduduk dengan urutan kulit putih, kulit berwarna (campuran), keturunan Asia (di sini biasanya orang India), dan orang Bantu (kulit hitam penduduk asli); kulit putih adalah ras beradab; kepentingan putih di atas hitam; dan kulit putih berbahasa Inggris. ${ }^{30}$

Pemisahan warga kulit putih dan hitam juga diberlakukan di fasilitas umum. Gedunggedung umum, transportasi umum, taman-taman, rumah makan, serta tentu sekolahsekolah, perguruan tinggi, rumah sakit dan gereja. Daerah-daerah permukiman di setiap kota dan desa juga dibagi dua, sistem pendidikan sekolah terpisah dengan kualitas guru yang berbeda, dan hanya warga kulit putih yang memiliki hak pilih. ${ }^{31}$

Besarnya diskriminasi antara golongan mendorong pihak yang terpinggirkan melakukan perlawanan. Gerakan massa yang terkenal adalah ketika adanya demonstrasi nasional pada 21 Maret 1960 yang dimotori oleh African National Congress (ANC) dan PanAfricanist Congress (PAC). Mereka memprotes Apartheid yang semakin hari semakin berdampak buruk, terutama masalah pekerjaan. Adanya desakan masa yang mendekati kantor polisi Afrika Selatan berimbas pada tindakan represif pihak kepolisian yang melepaskan tembakan kepada kerumunan. Tercatat 69 orang meninggal dunia akibat peristiwa itu. $^{32}$

Protes anti-apartheid terus berlanjut mengingat kehidupan orang kulit hitam Afrika Selatan semakin terdiskriminasi. Gelombang aksi dan peristiwa menjadi hal yang sering terjadi untuk mengakhiri sistem ini. Pada tahun 1989, Presiden Afrika Selatan, P. W. Botha mengundurkan diri karena alasan kesehatan yang memburuk dan kemudian digantikan oleh F.W. De Klerk (1989-1994). Hal ini kemudian menjadi babak baru terjadinya awal reformasi di Afrika Selatan.

Selama menjabat, De Klerk mengimplemetasikan usaha-usaha untuk mengakhiri diskriminasi terhadap warga. Pada tahun 1990, De Klerk mengakhiri pelarangan partai politik kaum kulit hitam, termasuk ANC. Selain itu, terdapat kebijakan melepaskan banyak tahanan tokoh kulit hitam dari penjara, diantaranya Nelson Mandela yang telah dipenjara sejak tahun $1964 .{ }^{33}$ Setelah melalui proses panjang, pada 1991 Presiden F.W. De Klerk, menghapus semua hukum apartheid dan berkomitmen mengahsilkan konstitusi baru. Pada 1993, transisi pemerintahan menuju era multiras dan multipartai disetujui. Setahun kemudian, Afrika Selatan menyelenggarakan pemilu pertama dan Nelson Mandela terpilih menjadi Presiden. ${ }^{34}$

Upaya untuk menciptakan hubungan yang lebih harmonis dan kondusif untuk pembangunan Afrika Selatan di mulai dari melakukan rekonsiliasi terhadap berbagai kasus kekerasan yang terjadi. Salah satu faktor penting tersebut adalah pembentukan TRC (Truth and Reconciliation Commission / Komisi Kebenaran dan Rekonsiliasi)

\footnotetext{
${ }^{30}$ Idem, hlm 19.

${ }^{31}$ Luky Setyarini, Apartheid di Afrika Selatan, loc.cit.

${ }^{32}$ Rifai Shodiq, Op.cit.

${ }^{33}$ Ibid.

${ }^{34}$ Rifa Nadia Nurfuadah, HISTORIPEDIA: Jalan Panjang Akhiri Apartheid di Afsel, dari Resolusi PBB hingga Kepresidenan Nelson https://news.okezone.com/read/2017/11/05/18/1808668/historipedia-jalan-panjang-akhiri-apartheid-diafsel-dari-resolusi-pbb-hingga-kepresidenan-nelson-mandela, diakses 20 November 2020.
} 
sebagai lembaga yang dibentuk khusus untuk menangani permasalahan kekerasan negara dan pelanggaran berat HAM di masa apartheid. Lembaga in bersifat Plural dan Independen. ${ }^{35}$ Pembentukan TRC didasarkan atas beberapa pemikiran sebagai berikut: rekonsiliasi Afrika Selatan didasarkan pada upaya untuk menghapuskan identitas rasial yang diciptakan oleh apartheid, menciptakan pemahaman bersama tentang nilai-nilai demokrasi pada kelompok yang terpecah, serta merupakan penguatan nilai-nilai religious dan kemanusiaan untuk memberikan maaf dan sebagai pelajaran agar tidak terulang lagi di masa depan. ${ }^{36}$

Tahap awal Lembaga adalah dengan melakukan proses seleksi publik terhadap komisioner dalam lembaga ini. Komisi ini dipimpin oleh Desmond Tutu yang juga sebagai seorang tokoh Kristen kulit hitam yang di hormati di Afrika Selatan. Beberapa wewenang penting dari TRC diantaranya adalah pemberian amnesty (pengampunan) kepada individu, program perlindungan saksi, melakukan penyelidikan dan pengumpulan bukti-bukti, mengadakan kesaksian subpoena (kesaksian wajib). ${ }^{37}$ Adanya wewenang memberikan amnesty secara mandiri oleh TRC merupakan hal yang paling penting dalam proses kerja TRC itu sendiri. Dengan hal ini, maka TRC bekerja secara Independen tanpa ada kepentingan politik dan tekanan dari pihak lain. TRC hanya bersandarkan pada kepentingan keadilan, kebenaran, serta untuk rekonsiliasi semata.

Proses pemberian amnesty dalam kasus Afrika Selatan didasarkan pada aturan-aturan yang disebutkan dalam Promotion of National Unity and Reconciliation Act yang juga disepakati dan disahkan dalam proses negosiasi. Untuk mendapatkan pengampunan, para pelaku kekerasan (polisi, militer dan agen dinas rahasia) disyaratkan untuk mengungkapkan detil-detil kekerasan yang dilakukan berkaitan dengan perintah yang didapatkan dan berbagai hal lainnya berkaitan dengan dokumen atau catatan yang dibuat berdasarkan perilaku tersebut. Jadi secara sederhana dapat dikatakan bahwa pemberian amnesty ditujukan pada setiap individu yang mengakui keterlibatan mereka dalam berbagai aksi kekerasan terhadap aktivis dan tokoh-tokoh gerakan kulit hitam secara individual. ${ }^{38}$

Salah satu pencapaian terbesar dari kinerja TRC adalah diadakannya public hearing terhadap ratusan bahkan ribuan kasus kekerasan yang terjadi pada masa apartheid antara tahun 1960 sampai dengan 1994. Setiap kasus yang diajukan sebagai public hearing mendapatkan perhatian publik secara luas, baik melalui media elektronik atau melalui

${ }^{35}$ Sifat plural yang dimaksud adalah keanggotaan lembaga ini tidak hanya terbatas dan tertutup untuk perwakilan dari pihak kulit hitam sebagai korban semata, namun juga melibatkan perwakilan dari kulit putih untuk menjadi anggotanya.

${ }^{36}$ Poin-poin ini disarikan dari uraian Brandon Hamber dalam Brandon Hamber, Ere Their Story Die: Truth and Justice Reconsiliation in South Africa, dalam Jurnal Race and Class, Institut Race Relations, Vol.4 (1), p; 61-79 dikutip dalam http://www.brandonhamber.com/publications /Journa1\%20Hamber\%20Race\%20and\%20Class.pdf, diakses 20 November 2020

37 Mark Freeman \& Priscillia B. Hayner, the Truth Commission of South Africa and Guatemala International Center for Transitional Justice, p: 2, dalam: http://www.idea.int/publications/reconciliation/upload/reconciliation_chap08cs-safrica.pdf, diakses 20 November 2020.

${ }^{38}$ Victory Pradhitama, “Menggali Keadilan untuk Masa Lalu: Belajar Afrika Selatan”, Jurnal Studi Hubungan Internasional, Vol. 1, No.1, Tahun 2011, hlm 29. 
media cetak. Public hearing yang diadakan oleh TRC menjadi salah satu kegiatan dalam proses transisi yang menjadi perhatian utama masyarakat. ${ }^{39}$

TRC tidak hanya terfokus pada penggalian informasi yang berkaitan dengan pelaku tindakan kekerasan tetapi juga menyajikan perspektif korban berkaitan dengan peristiwa tersebut. TRC mempublikasikan serta mendokumentasikan berbagai narasi kesaksian dan cerita tentang penderitaan korban akibat kekerasan. Bagian akhir tugas TRC adalah membuat laporan analisis yang menguraikan tentang ide-ide atau kebijakan yang harus dilakukan oleh Pemerintah untuk mencegah terulangnya kejadian semacam ini di masa depan, dan rekomendasi terhadap bentuk pemulihan kondisi para korban. ${ }^{40}$

Hal yang tidak kalah penting dalam mendukung proses penyelesaian pelanggaran HAM di Afrika Selatan adalah tidak adanya campur tangan militer dalam setiap kinerja kelembagaan TRC. Militer cenderung bersifat pasif dan mengikuti proses yang menjadi tugas dari TRC/KKR. Posisi militer ini sangat menentukan, sebab apabila militer turut aktif dalam proses penyelesaian pelanggaran HAM maka peristiwa kekerasan tidak akan terungkap sepenuhnya karena adanya intervensi institusi.

Adanya sifat 'soft' dari militer ini tentu tidak lepas dari ketokohan seorang pemimpin yang mampu memberikan pemahaman serta pencerahan terhadap setiap institusi dibawah pimpinannya, dan hal ini dipraktikkan secara paripurna oleh Nelson mandel sebagai Presiden Afrika Selatan saat itu. Selain sebagai korban yang pernah menglami kekejaman sistem Apartheid, keberadaan Nelson Mandela tersebut ternyata mampu memprakarsai lahirnya TRC dan memberikan contoh kepemimpinan yang baik kepada seluruh dunia, bahwa sebagai seorang korban tidak semata-mata harus selalu menyimpan dendam terhadap apa yang telah dilaluinya.

\section{Proses Penyelesaian Pelanggaran HAM di Indonesia Kedepan}

Seperti yang disebutkan pada bahasan sebelumnya bahwa proses penyelesaian pelanggaran HAM di Afrika Selatan menjadi rujukan internasional, utamanya terkait dengan keberadaan serta kelembagaan Komisi Kebenaran dan Rekonsiliasinya. Bukan hanya berhasil secara kelembagaan KKR semata, Afrika Selatan juga dapat meminimalkan konflik yang terjadi selama masa transisi atau bahkan setelah tugas KKR diakhiri.

Beberapa faktor yang dapat penting yang dapat dijadikan pelajaran bagi proses penyelesaian pelanggaran HAM di negara lain, termasuk di Indoneisa adalah proses transisi politik yang melahirkan rezim kepemimpinan yang mempunyai kapasitas serta mendapat pengakuan sepenuhnya dari seluruh elemen negara turut serta menghasilkan kelembagaan KKR dalam rangka menyelesaikan persoalan HAM yang pernah terjadi. Selain itu, TRC/KKR di Afrika Selatan juga memiliki wewenang yang jelas serta bersifat plural dan independen. Hal ini tentu sangat jarang diberikan oleh negara lain kepada lembaga diluar pengadilan untuk menyelesaikan kasus pelanggaran HAM. Pemahaman yang berkembang dalam konteks negara hukum, penyelesaian suatu masalah lebih ditekankan pada proses yudisial semata. Hal ini tentu akan semakin mempersulit proses penyelesaian suatu masalah, khususnya terkait pelanggaran HAM yang konteks pembuktian dan kasusnya sangat rumit dan telah terjadi bahkan sebelum pengadilan itu terbentuk. Oleh sebab itu, adanya kelembagaan KKR ini sangat penting

\footnotetext{
${ }^{39}$ Idem, hlm 29.

${ }^{40}$ Idem, hlm 30.
} 
untuk melakukan proses penyelesaian HAM secara keseluruhan. Hal ini tentu senafas dengan apa yang menjadi amanat dalam putusan Mahkamah Konstitusi Nomor 006/PUU-IV/2006, yang secara garis besar tidak menutup ruang untuk proses rekonsiliasi dalam penyelesaian pelanggaran HAM diluar pengadilan.

Beberapa hal efektif yang dipraktekan di Afrika Selatan tersebut seharusnya menjadi pertimbangan utama dalam pembentukan KKR di Indonesia. Seluruh stakeholder harus memiliki kemauan dan keberanian untuk turut serta menyelesaikan proses pelanggaran HAM yang pernah terjadi. Adanya kepentingan individu/kelompok bahkan egosektoral kelembagaan harus dipinggirkan terlebih dahulu dalam rangka menyelesaikan persoalan HAM. Hal ini dikarenakan, proses pelanggaran HAM tidak hanya dilakukan oleh salah satu pihak semata, melainkan melibatkan berbagai pihak yang semakin menambah rumit proses penyelesainnya.

Oleh sebab itu, adanya ruang yang diberikan melalui putusan MK tersebut harus ditindaklanjuti secara efektif oleh pemerintahan yang ada. Substansi kelembagaan KKR yang pernah dibatalkan oleh MK terdahulu tidak lagi menjadi rumusan yang baru dalam rencana pembentukan KKR yang baru. Hal ini dimaksudkan agar pembentukan KKR di Indonesia tidak hanya 'berganti baju' sebagaimana UU yang pernah dibatalkan oleh MK.

Proses panjang penyelesaian pelanggaran HAM ini tentu tidak akan efektif apabila pemerintah hanya bersifat pasif atau hanya mengeluarkan kebijakan 'setengah hati' dalam menyelesaikan pelanggaran HAM. Menurut penulis pemerintah harus berani mengambil langkah maju dalam proses penyelesaian HAM di Indonesia. Sebelum adanya pembentukan KKR, seharusnya seluruh pemegang kekuasaan dinegeri ini bersepakat terlebih dahulu terkait penyelesaian HAM yang ada. Hal ini sangat penting agar tidak terjadi perbedaan kebijakan antara masing-masing pemangku kepentingan. Tidak adanya tokoh yang sama perjalannya seperti Nelson Mandela, tidak dapat menjadi alasan untuk menghambat penyelesaian perkara HAM di Indonesia.

Langkah selanjutnya adalah adanya ruang aspirasi yang terbuka dari masyarakat tentang rencana kelembagaan KKR di Indonesia. Hal ini penting dilakukan apabila usulan pembentukan KKR hanya berasal dari pemerintah maka subjektivitas pemerintah-pu akan semakin terlihat dan berbagai kepentingan dalam unsur pemerintahan akan ikut campur dalam pembentukan KKR tersebut. ${ }^{41}$ Apabila mekanisme dan substansi pembentukan KKR ini dapat menampung seluruh aspirasi masyarakat (utamanya korban pelanggaran HAM) maka akan tercipta puclic trust terhadap kelembagan KKR. Hal ini tentu akan menjamin kredibilitas KKR.

Langkah yang tidak kalah penting adalah penataan kelembagaan KKR yang efekif, bukan hanya sifatnya yang seharusnya bersifat pluralistik dan mandiri seperti yang ada di Afrika Selatan, tugas dan fungsi KKR di Indonesia harus lebih konkrit dan dikuatkan, misalnya dengan jenjang waktu penyelesaian pelanggaran HAM yang diberikan periode waktu yang panjang. Seperi diketahui, UU KKR yang dibatalkan hanya memberikan waktu yang singkat dalam proses penyelesainnya. Hal ini tentu tidak akan berimbas pada efektivitas kinerja dan kelembagaan KKR. Hal lainya misalnya dapat dilakukan dengan pemberian kompensasi kepada para korban yang tersebar di seluruh Indonesia.

\footnotetext{
${ }^{41}$ Seperti dikatahui, hingga saat ini masih banya aktor yang menjadi dalang atau turut terlibat dalam pelanggaran HAM yang pernah terjdi di Indonesia, baik dalam unsur pemerintahan, maupun dalam lembaga pengawas pemerintahan seperti parlemen.
} 
Adanya kompensasi berbentuk nominal uang ganti rugi tertentu tentuk hanya akan dapat dimanfaatkan dalam waktun yang tidak lama. Langkah yang bisa dilakukan adalah dengan pemberian kompenasasi yang efektif, semisal jaminan sosial atau jaminan pendidikan terhadap keluarga korban, atau bahkan dapat diberikan lahan atau pekerjaan dalam menunjang kehidupan keluraga korban.

Secara kelembagaan, hal yang paling mendasar pula adalah penyemaan persepsi antar setiap orang yang akan menduduki keanggotan dalam KKR. Hal ini sangat efektif untuk menunjang kinerja kelembagaan KKR. Adanya gagasan dan tujuan yang sama antar masing-masing anggota dan didukung oleh leadership yang mumpuni akan menentukan proses penyelesaian pelanggaran HAM. Oleh sebab itu, proses rekrutmen keanggotan KKR harus diatur sedemikian rupa dalam peraturan perundang-undangan yang akan menjadi dasar kelembagaan KKR.

Terakhir, adanya peran dan kelembagaan KKR ini tidak akan menjadikan proses peradilan yang ada di Indonesia akan dihilangkan secara sepenuhnya. Lahirnya kelembagan KKR kedepan harus dipandang sebagi bentuk kolaborasi yang efektif dalam proses penyelesaian pelanggaran HAM di Indonesia. Secara substansial, peristiwa pelanggaran HAM merupakan peristiwa yang memiliki kompleksitas dan mengandung unsur politis tinggi, terlebih yang dilakukan oleh negara pada masa pemerintahan yang lalu. Oleh sebab itu, dibutuhkan kemauan dan keberanian dari seluruh pihak untuk menyelesaikan persoalan ini. Langkah itu harus diimplementsikan secara jelas dalam kelembagaan yang efektif.

\section{SIMPULAN}

Kompleksitas dan adanya unsur politis yang tinggi dalam setiap eskalasi pelanggaran HAM yang terjadi merupakan hal yang tidak dapat dihindari, terlebih lagi pelanggaran tersebut dilakukan oleh negara kepada rakyanya melalui rezim pemerintahan yang otoriter. Oleh sebab itu proses penyelesainnya tidak harus menumpuk pada badan peradilan semata. Keberadaan Komisi Kebenaran dan Rekonsiliasi harus dipandang sebagai salah satu media efektif dalam menyelesaiakan setiap pelanggaran HAM yang terjadi

Keberhasilan Komisi Kebenaran dan Rekonsiliasi di Afrika Selatan seharusnya menjadi rujukan utama proses penyelesaian Ham diluar pengadilan oleh negara lain, termasuk Indonesia. Adanya efektivitas kelembagaan melalui tugas, fungsi serta peraturan yang jelas akan turut menunjujang keberhasilan kinerja lembaga ini. Tokoh nasional yang menjadi icon dan jembatan penyelesaian HAM turut berpengaruh dal proses penyelesaian HAM. Oleh sebab itu, adanya ruang yang diberikan oleh Mahkamah Konstitusi agar proses penyelesaian pelanggaran HAM dapat dilakukan melalui proses rekonsiliasi harus ditindaklanjuti oleh pemerintah secara cepat dan tepat. Jangan sampai substansi UU dan kelembagaan yang pernah dibatalkan terahulu akan termauat pada rencana opembentukn KKR kedepan. Oleh sebab itu, penting untuk menetukan krieria serta sifat kelembagaan guna menunjang keefektivan lembaga ini.

\section{DAFTAR PUSTAKA}

\section{Buku:}

Bahder Johan Nasution, Metode Penelitian Ilmu Hukum, Bandung: Mandar Maju, 2008. 
Janedri M.Gaffar, Demokrasi Konstitusional: Praktik Ketatanegaraan Indonesia Setelah Perubahan UUD 1945, Jakarta: Konstitusi Press, 2012.

Ifdhal Kasim, Briefing Paper Series Tentang Komisi Kebenaran dan Rekonsiliasi. Jakarta: Lembaga Studi dan Advokasi Masyarakat, 2000.

Soerjono Soekanto dan Sri Mamudji, Penelitian Hukum Normatif Suatu Tujuan Singkat, Cetakan ke-11, Jakarta: PT Raja Grafindo Persada, 2014.

\section{Jurnal}

Agus Budiman, "Politik Apartheid di Afrika Selatan", Jurnal Artefak, Vol. 1, No. 1, Januari 2013.

Brandon Hamber, "Ere Their Story Die: Truth and Justice Reconsiliation in South Africa", dalam Jurnal Race and Class, Institut Race Relations, Vol.4 (1). Lihat http://www.brandonhamber.com/publicationsJournal\%20Hamber\%20

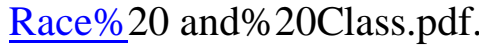

Bagir Manan dan Susi Dwi Harijanti, "Konstitusi dan Hak Asasi Manusia", Padjajaran Jurnal Ilmu Hukum, Vol. 3, No.3, Tahun 2016.

Fajar Laksono Soeroso, "Aspek Keadilan Dalam Sifat Final Putusan Mahkamah Konstitusi”, Jurnal Konstitusi, Vol. 11, No.1, Maret 2014

Firdiansyah, "Peran dan Harapan Korban Untuk Penyelesaian Pelanggaran HAM Masa Lalu", Jurnal HAM Komnas HAM, Vol. XIII. Tahun 2016

Mark Freeman \& Priscillia B. Hayner, The Truth Commission of South Africa and Guatemala International Center for Transitional Justice. Lihat http://www.idea.int/publications/reconciliation/upload/reconciliation_chap0 8cs-safrica.pdf.

Victory Pradhitama, "Menggali Keadilan untuk Masa Lalu: Belajar Afrika Selatan", Jurnal Studi Hubungan Internasional, Vol. 1, No.1, Tahun 2011.

\section{Peraturan Perundang-Undangan}

Undang-Undang Dasar Negara Republik Indonesia Tahun 1945

Undang-Undang Nomor 39 Tahun 1999 Tentang Hak Asasi Manusia

Undang-Undang Nomor 27 Tahun 2004 tentang Komisi Kebenaran dan Rekonsiliasi

Putusan Mahkamah Konstitusi Nomor 006/PUU-IV/2006 Tentang Pengujian UndangUndang Nomor 27 Tahun 2004 Tentang Komisi Kebenaran dan Rekonsiliasi

\section{Sumber Lain}

Febriana Firdaus, Lima Kasus Besar Pelanggaran HAM di Indonesia, https://www.rappler.com/world/regions/asia-pacific/indonesia/77617-limakasus-besar-pelanggaran-ham-di-indonesia

Lembaga Studi dan Advokasi Masyarakat, Mendorong Pembentukan Kembali UU Komisi Kebenaran dan Rekonsiliasi, Pandangan ELSAM Mengenai Pentingnya RUU Komisi Kebenaran dan Rekonsiliasi Luky Setyarini, Apartheid di Afrika Selatan-Dunia Hitam-Putih, 
https://www.dw.com/id/apartheid-di-afrika-selatan-dunia-hitamputih/a 5239303.

Rakaryan Sukarjaputra, Konflik dan Pelanggaran HAM Catatan Kelam 20 tahun Reformasi, https://nasional.kompas.com/jeo/konflik-dan-pelanggaran-hamcatatan-kelam-20-tahun-reformasi

Rifa Nadia Nurfuadah, HISTORIPEDIA: Jalan Panjang Akhiri Apartheid Di Afsel, dari Resolusi PBB hingga Kepresidenan Nelson Mandela, https://news.okezone.com/read/2017/11/05/18/1808668/historipedia-jalanpanjang-akhiri-apartheid-di-afsel-dari-resolusi-pbb-hingga-kepresidenannelson-mandela

Rifai Shodiq Fathoni, Politik Apartheid di Afrika Selatan 1948-1994 M, https://wawasansejarah.com/politik-apartheid-di-afrika-selatan/

Ringkasan Eksekutif, Laporan Penyelidikan Pelanggaran Ham Yang Berat, Jakarta : Komnas HAM.

Tim Monitoring dan Dokumentasi SETARA Institute, Data Pelanggaran Hak Asasi manusia di Indonesia, http://setara-institute.org/wpcontent/uploads/2015/09/Data-Pelanggaran-Hak-Asasi-Manusia-diIndonesia.pdf. 